\title{
Correction to: New Exotic Minimal Sets from Pseudo-Suspensions of Cantor Systems
}

\author{
Jan P. Boronski ${ }^{1,2}(D)$ Alex Clark $^{3} \cdot$ Piotr Oprocha ${ }^{1,2}$
}

(c) The Author(s) 2021

\section{Correction to: Journal of Dynamics and Differential Equations https://doi.org/10.1007/s10884-021-10069-3}

The original version of this article unfortunately contained error in Alex Clark's affiliation and missed to include his e-mail address.

The author Alex Clark is affiliated to School of Mathematical Sciences, Queen Mary University of London, Mile End Road, London E1 4NS, UK but instead the article was published with incorrect affiliation and his e-mail address is alex.clark@qmul.ac.uk

Now, the authors are presented with their correct affiliations.

The original article has been corrected.

Open Access This article is licensed under a Creative Commons Attribution 4.0 International License, which permits use, sharing, adaptation, distribution and reproduction in any medium or format, as long as you give appropriate credit to the original author(s) and the source, provide a link to the Creative Commons licence, and indicate if changes were made. The images or other third party material in this article are included in the article's Creative Commons licence, unless indicated otherwise in a credit line to the material. If material is not included in the article's Creative Commons licence and your intended use is not permitted by statutory regulation or exceeds the permitted use, you will need to obtain permission directly from the copyright holder. To view a copy of this licence, visit http://creativecommons.org/licenses/by/4.0/.

Publisher's Note Springer Nature remains neutral with regard to jurisdictional claims in published maps and institutional affiliations.

The original article can be found online at https://doi.org/10.1007/s10884-021-10069-3.

Jan P. Boronski

boronski@agh.edu.pl

Alex Clark

alex.clark@qmul.ac.uk

Piotr Oprocha

oprocha@agh.edu.pl

1 Faculty of Applied Mathematics, AGH University of Science and Technology, al. Mickiewicza 30, 30-059 Kraków, Poland

2 National Supercomputing Centre IT4Innovations, Division of the University of Ostrava, Institute for Research and Applications of Fuzzy Modeling, 30. dubna 22, 70103 Ostrava, Czech Republic

3 School of Mathematical Sciences, Queen Mary University of London, Mile End Road, London E1 4NS, UK 